logos_i_ethos_2017_(45)_numer specjalny, s. 29-51

DOI: http://dx.doi.org/10.15633/lie.2336

Sławomir Drelich

Uniwersytet Mikołaja Kopernika w Toruniu

\title{
Ucieczka od umiaru. Polityka w erze mediów masowych
}

\section{Koniec ery rozumu - wprowadzenie}

Jeśli rację miał Arystoteles, to polityka jest działalnością, bez której trudno wyobrazić sobie funkcjonowanie świata społecznego, a wówczas świadomość tego, jak sfera polityczna przeobraziła się w toku dziejów, może nam wiele powiedzieć o człowieku jako takim. Leo Strauss przypomina przekonanie Stagiryty, iż „stowarzyszenie polityczne istnieje $\mathrm{z}$ natury, a człowiek jest istotą z natury polityczną, gdyż jest obdarzony rozumem czy mową, co umożliwia najbliższe zjednoczenie z innymi: zjednoczenie w czystej myśli" ${ }^{1}$. Rozum i mowa to - w klasycznej wizji polityki i człowieka jako jej podstawowego podmiotu - warunki sine qua non człowieczeństwa, jednakże analizując funkcjonowanie współczesnych mediów masowych, w coraz większym stopniu można dostrzec kryzys w obu tych obszarach. Zdaniem Giovanniego Sartoriego człowiek jest swoistym animal symbolicum, gdyż posiadł umiejętność myślenia abstrakcyjnego, dzięki niemu zaś nauczył się „wytwarzania” symboli. Jak wskazuje autor eseju Homo videns. Telewizja i postmyślenie, „tę zdolność tworzenia symboli przez istotę ludzką wyraża język, czyli umiejętność porozumiewania się za pomocą artykułowanych

1 L. Strauss, Sokratejskie pytania, przeł. P. Śpiewak, Warszawa 1998, s. 26.
Sławomir Drelich, dr, politolog i etyk, adiunkt na Wydziale Politologii i Studiów Międzynarodowych Uniwersytetu Mikołaja Kopernika w Toruniu; publicysta w kwartalniku nego, dyskursem publicznym i myślą polityczną (populizmem, liberalizmem i libertaianizmem); autor książek Populistów ethos na ludowego. Przypadek Andrzeja Leppera, Toruń 2013. 
dźwięków i znaków «znaczących», znaków wyposażonych w znaczenia”2. Sartori jednakowoż stawia tezę, że od początku ery telewizji człowiek coraz bardziej oddala się od ideału animal symbolicum, przekształcając się w zastraszającym tempie $\mathrm{w}$ istotę określaną przezeń jako homo videns. Istota ta przestaje myśleć abstrakcyjnie i z wolna zatraca swoją zdolność wytwarzania form symbolicznych, zaś skupia się przede wszystkim na myśleniu konkretnym, a głównym środkiem komunikowania i przekazu staje się już nie mowa i język, lecz obraz. „Odchodzenie od rozumu” dostrzegalne jest w wielości zjawisk, które zostały wygenerowane przez współczesne media masowe. Jednym $\mathrm{z}$ tych zjawisk jest niewątpliwie zerwanie $\mathrm{z}$ ideałem umiaru i rozsądku przez sferę polityczną. Przedstawiciele tej sfery stali się jednym z najaktywniejszych aktorów współczesnej sceny medialnej. Celem niniejszego tekstu jest wskazanie przejawów tejże „ucieczki od umiaru”, na którą zapadli współcześni politycy. Ta ucieczka od umiaru wypływa rzecz jasna z samej natury mediów masowych, jednakże nie bez znaczenia dla tego procesu są także takie zjawiska, jak: komercjalizacja kolejnych sfer życia człowieka, urynkowienie relacji międzyludzkich, „technicyzacja” i profesjonalizacja polityki itp.

Strauss przypominał również inny pogląd Stagiryty, że „najlepsze jest życie poświęcone rozmyślaniu czy też kontemplacji, w przeciwieństwie do życia praktycznego czy politycznego. Tym samym wiedza praktyczna jest czymś niższym niż wiedza teoretyczna, która dotyczy rzeczy boskich czy struktury świata”3. Widzimy więc, że w koncepcji klasycznej działalność polityczna nie zyskiwała rangi vita contemplativa, a współczesne procesy w jeszcze bardziej oddalają ją od tego ideału. Jak zostanie wykazane w niniejszym tekście, w coraz większym stopniu zmediatyzowana polityka zaczęła uzależniać się od sektora rozrywki, zaś za swoją podstawową metodę działania przyjmować manipulację i socjotechnikę. Zgodnie z założeniem Marshalla McLuhana, „każdy nowy przekaźnik, tj. każde «przedłużenie» nas samych czy wszelka nowa technika, wpływają na życie jednostki i społeczeństwa w ten sposób, że rozszerzają skalę naszego ży-

2 G. Sartori, Homo videns. Telewizja i postmyślenie, przeł. J. Uszyński, Warszawa 2007, s. 15.

3 L. Strauss, Sokratejskie pytania, dz. cyt., s. 35. 


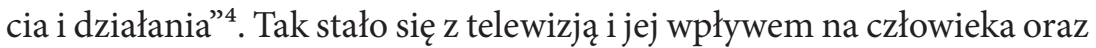
relacje międzyludzkie. Polityka również „oberwała rykoszetem” i upodobniła się do człowieka zmediatyzowanego: biernego, uległego, otępiałego. Ponieważ - zgodnie ze słowami Pierre’a Bourdieu - „w telewizji nie da się powiedzieć niczego ważnego, a już zwłaszcza, gdy chce się mówić o samej telewizji" ${ }^{5}$, w efekcie również politycy generują przekaz polityczny, którego treść staje się coraz bardziej ograniczona, żeby nie powiedzieć: przekaz ten zostaje wyzuty z wszelkiej merytorycznej, lecz również ideologicznej treści. Coraz trudniej mówić więc o ideale dobrego polityka czy dobrze zorganizowanego państwa, rację bytu traci również refleksja nad wychowaniem dobrego obywatela. Można przypomnieć pytanie, jakie w Demokracji i jej krytykach postawił Robert A. Dahl: „Czy powinniśmy zatem w ogóle zrezygnować z poszukiwań doskonałych pod względem filozoficznym materialnych zasad wspólnego dobra i dążyć w zamian do praktycznie doskonałych procedur jego osiągania?"”. Przez analogię moglibyśmy zapytać: czy powinniśmy zatem w ogóle zrezygnować z poszukiwań ideału polityka czy też dobrze zorganizowanych mediów masowych? Wydaje się, że nie, jednak w pierwszej kolejności musimy szczegółowiej przyjrzeć się temu, co uniemożliwia taką refleksję filozoficzną czy etyczną, a bez wątpienia jednym $\mathrm{z}$ ważniejszych powodów jest wspominana ucieczka od umiaru - choroba, na którą gremialnie zapadają politycy w dobie mediów masowych.

\section{Polityka jako rozrywka}

Polityka w jej wersji klasycznej miała być działalnością ukierunkowaną na zbudowanie dobrego państwa, którym rządziliby dobrzy politycy, wykonujący swoje obowiązki na rzecz dobrych obywateli. Zdając sobie

${ }^{4}$ M. McLuhan, Przekaźniki, czyli przedłużenie człowieka, w: M. McLuhan, Wybór pism: Przekaźniki, czyli przedłużenie człowieka; Galaktyka Gutenberga; Poza punktem zbiegu, przeł. K. Jakubowicz, Warszawa 1975, s. 45.

5 P. Bourdieu, O telewizji. Panowanie dziennikarstwa, przeł. K. Sztandar-Sztanderska, Warszawa 2009, s. 37.

${ }^{6}$ R. A. Dahl, Demokracja i jej krytycy, przeł. S. Amsterdamski, Warszawa 2012, s. 433. 
sprawę z utopijności tak rozumianej wizji polityki, trzeba jednakowoż pamiętać, że stawiała sobie ona przynajmniej górnolotne cele, próbując tym samym uzasadnić je etycznie. Polityka współczesna nie chce stawiać sobie wyśrubowanych celów, tym bardziej zaś nie zamierza budować dla nich etycznych uzasadnień. W ogóle wszelka argumentacja, która opierałaby się na wartościach, jest ze sfery politycznej systematycznie usuwana. Strauss podkreśla, że „odrzucenie sądów wartościujących jest oparte na założeniu, że konflikty pomiędzy różnymi wartościami czy systemami wartości są z istoty swej nierozwiązywalne dla rozumu ludzkiego. Lecz to założenie, choć powszechnie uważane za obowiązujące, nigdy nie zostało dowiedzione" ${ }^{\prime 7}$. Jeśli więc konflikty dotyczące wartości rzeczywiście są nierozwiązywalne, to dlaczego nie wyrugować wartości z wszelkiej działalności i refleksji politycznej czy politologicznej? Paradoksalnie jednak powstrzymanie się od stawiania pytań natury etycznej w połączeniu ze zjawiskiem mediatyzacji i marketyzacji polityki poskutkowało radykalnym zbliżeniem się działalności politycznej do rozrywki. „Politrozrywka” - jak nazywa tę nową formę uprawiania polityki Tomasz Olczyk ${ }^{8}$ - nie tylko zrezygnowała $\mathrm{z}$ roszczeń, jakie stawiali sobie filozofowie polityczni doby klasycznej, ale uczyniła z polityki działalność, której zasadnicza część rozgrywa się jako przejaw usług rozrywkowych. Olczyk obawia się, że proces ten jest nie do odwrócenia, nie wierzy, by dążenia do „całkowitego wyrugowania "politrozrywki» czy jakakolwiek odgórna reforma dyskursu medialnego w stronę jego «uracjonalnienia» była możliwa do zrealizowania"9. Już ponad trzydzieści lat temu Krzysztof Teodor Toeplitz w swoich Szkicach edynburskich dostrzegł, że „telewizja jest doniosłym społecznie sposobem spędzania wolnego czasu" ${ }^{10}$. Wydaje się jednak, że samoredukowanie się działalności politycznej do obecności w mediach masowych i branie na siebie przede wszystkim ról z tejże obecności wynikających, to wizja zdecydowanie niewystarczająca i tym samym nie-

7 L. Strauss, Sokratejskie pytania, dz. cyt., s. 74.

8 Zob. T. Olczyk, Politrozrywka i popperswazja. Reklama polityczna w polskich kampaniach wyborczych XXI wieku, Warszawa 2009.

9 T. Olczyk, Politrozrywka i popperswazja..., dz. cyt., s. 527.

10 K. T. Toeplitz, Szkice edynburskie, czyli system telewizji, Warszawa 1979, s. 18. 
przystająca do zakresu kompetencji, które politycy uzyskują w ustrojach demokratycznych. To również - co w przypadku demokracji zdaje się szczególnie istotne - zdecydowanie nie przystaje do oczekiwań, jakie społeczeństwa demokratyczne mają względem swoich politycznych elit.

Toeplitz wskazuje jednak, że rozrywka jako taka nigdy nie powinna być negatywnie wartościowana. Przekonuje, że „szeroko rozumiana rozrywka - zwłaszcza we współczesnych społeczeństwach wielkoprzemysłowych - będąc [...] rodzajem ucieczki od życia, może stać się również w szczególny sposób miarą jego wartości”" ${ }^{11}$. Korzystanie z różnych atrakcji współczesnej kultury, dzięki którym możemy oderwać się od codziennych zobowiązań i aktywności, może się stać - zdaniem Toeplitza - działaniem wartościowym, gdyż pozwalającym z pewnego dystansu spojrzeć na otaczającą nas rzeczywistość, a także na nasze życie. Trudno jednak iść tropem przez niego wskazanym i próbować uzasadniać czy wręcz usprawiedliwiać sprowadzenie polityki do roli samej tylko rozrywki. Peter Sloterdijk wskazuje, że „współczesne społeczeństwo zgodnie ze swoją logiką słusznie zastąpiło świętych sportowcami wyczynowymi - a grzeszną większość widzami”" ${ }^{\prime 2}$. Takim sposobem do wspominanych przez niego „sportowców wyczynowych” dołączyli również politycy, którzy stali się marionetkami spektaklu oglądanego przez opinię publiczną. Politycy tak zanurzeni w sferze rozrywkowej ulegają stopniowej „disneizacji”. O zjawisku tym pisał - powołując się na Allana Brymana - Wojciech Chudy w swoim Eseju o społeczeństwie i kłamstwie. Zjawisko „disneizacji” - jego zdaniem - „wyznacza kulturę według parków tematycznych Walta Disneya. Jej wyznacznikami są tematyczność, unifikacja konsumpcji, gadżetowość i dyspozycyjność emocjonalna" ${ }^{13}$. Nie ma wątpliwości, że takiemu procesowi podlega również zmediatyzowana polityka. Jej tematyczność przejawia się w hasłowym i z reguły sensacyjno-emocjonalnym dyskursie, przy pomocy którego politycy

11 K. T. Toeplitz, Szkice edynburskie..., dz. cyt., s. 73.

12 P. Sloterdijk, Pogarda mas, przeł. B. Baran, Warszawa 2012, s. 127.

13 W. Chudy, Społeczeństwo zakłamane. Esej o społeczeństwie i kłamstwie - 1, Warszawa 2007, s. 262 . 
komunikują się ze społeczeństwem; unifikacja konsumpcji dostrzegalna jest w ujednolicaniu oferty politycznej różnych środowisk politycznych, a także w wykorzystywaniu przez nie podobnych - lub wręcz identycznych - mechanizmów komunikacji politycznej czy kreowaniu wizerunku politycznego; gadżetowatość dostrzeżemy, analizując konkretne działania sztabów w kampaniach wyborczych; natomiast dyspozycyjność emocjonalna przejawia się w ukierunkowanym na sensacyjność i wyrazistość przekazie werbalnym przywódców politycznych. Bourdieu interpretuje takie działania jako „populistyczną spontaniczność i demagogiczną uległość wobec ludowego gustu”" ${ }^{14}$. De facto więc zjawisko to infantylizuje polityków, ujmuje im powagi, a tym samym ze sfery politycznej czyni działalność analogiczną do uczestnictwa w programach typu reality show.

Politycy w erze mediów masowych stają się współczesnymi celebrytami, którzy starają się zbudować swój wizerunek jako „Zwykłych ludzi”, „ludzi z ludu” czy też „ludzi takich jak wszyscy”. Epatują swoim życiem rodzinnym, dzielą się na portalach społecznościowych swoimi zainteresowaniami czy pasjami, relacjonują podróże oraz wyjazdy służbowe, a także toczą spory - mniej lub bardziej poważne - ze swoimi politycznymi adwersarzami. Mamy niewątpliwie do czynienia z przejawem kultury obnażania, która za pośrednictwem mediów masowych wdarła się także do sfery politycznej. Brian McNair podkreśla, że „zjawisko kultury obnażania w przeznaczonych dla szerokiej publiczności środkach masowego przekazu wskazuje na istnienie szerokiego sektora podglądaczy"15, co jednakże nie powinno nas szczególnie dziwić, gdyż właściwie od zawsze przedstawiciele elit społecznych czy politycznych skupiali na sobie uwagę społecznych mas. Sloterdijk stwierdza, że to „pod wpływem mass mediów medialne masy niewątpliwie stały się barwną czy też molekularną masą" ${ }^{16}$. Trudno jednakże wnioskować, czy owa „barwna czy też molekularna masa” prezentuje tą tęczą kolorów jakiś konstruktywny przekaz

14 P. Bourdieu, O telewizj..., dz. cyt., s. 80.

15 B. McNair, Seks, demokratyzacja pożądania i media, czyli kultura obnażania, przeł. E. Klekot, Warszawa 2004, s. 181.

16 P. Sloterdijk, Pogarda mas, dz. cyt., s. 27. 
dotyczący samej siebie, czy też raczej cała ta paleta kolorów jest jedynie Baudrillardowskim symulakrem, w większym stopniu zakrywającym niż odsłaniającym. Zapewne rację ma Toeplitz, którego zdaniem korzystający z tychże dobrodziejstw rozrywkowej kultury medialnej „człowiek czuje się oderwany od codziennej szarzyzny życia, jeśli działaniom swoim nada charakter wyjątkowości, odświętności” ${ }^{17}$. Jednakże należy pamiętać, że telewizja i obcowanie za jej pośrednictwem ze sferą polityczną rzadko budują taką wyjątkowość czy odświętność. Obserwacja teatru sfery politycznej staje się raczej codziennością, która rzadko widza zaskakuje, zaś jeszcze rzadziej skłania go do podjęcia działania będącego odpowiedzią na komunikaty płynące ze strony tej sfery. Wątpi w istnienie takiej potencjalnej wyjątkowości czy odświętności również Bourdieu, podkreślając, iż „im bardziej jakaś gazeta lub jakiekolwiek inne medium chce przyciągnąć do siebie szeroką publiczność, tym bardziej musi dbać, by to, co przekazuje, nie było chropowate, by nie dzieliło ani nie wykluczało odbiorców" ${ }^{18}$. Taki relaksująco-rozrywkowy przekaz - także generowany przez polityków - powinien być na tyle niekontrowersyjny i uniwersalny, aby zainteresował większość obserwatorów. Wyklucza to rzecz jasna możliwość szerszego rozpropagowywania wyrazistych wartości i idei, które domagają się zajęcia zdecydowanej postawy moralnej czy wartościującej.

Polityka współczesna postrzegana jako rozrywka zaczyna systematycznie ewoluować w kierunku swoistej „wideokracji”, która - zdaniem Sartoriego - „wytwarza na skalę masową opinie zewnątrzsterowne; ta produkcja tylko pozornie wzmacnia, a w istocie osłabia, ustrój demokratyczny rozumiany jako rządy opinii”" ${ }^{\prime 19}$. Z pozoru mogłoby się wydawać, że media masowe - szczególnie telewizja - zbliżają człowieka do polityki i spraw publicznych, w rzeczywistości jednak upraszczają one jeszcze bardziej wiedzę polityczną, tworząc jednocześnie złudzenie, że samo obcowanie z polityką zapośredniczone przez media jest już uczestnictwem w życiu publicznym. Polityka serwowana jako telewizyjna rozrywka nie

17 K. T. Toeplitz, Szkice edynburskie..., dz. cyt., s. 76.

18 P. Bourdieu, O telewizji..., dz. cyt., s. 75.

19 G. Sartori, Homo videns..., dz. cyt., s. 41. 
aktywizuje człowieka, ale czyni go jeszcze bardziej biernym. Wydawałoby się, że w rozbudzeniu ludzkich zainteresowań, w tym również zainteresowania sferą publiczną, „pomaga dzisiaj ogromny przemysł oferujący różne formy spędzania czasu wolnego. Najczęściej zresztą wyłącznie pasywne - dostarczają nam one wprawdzie rozrywki, ale nie dają prawdziwego flow" ${ }^{20}$. Zmediatyzowana polityka nie jest więc niczym więcej, jak czystą rozrywką, a oglądany na ekranach telewizorów polityczny spektakl de facto nie jest niczym więcej, jak kolejnym serialem telewizyjnym, kolejną mydlaną operą czy też reality show. Jedynie w pewnym stopniu „świat rozrywki, poprzez celebrowanie swoich własnych sukcesów, poprzez system gwiazd i idoli, stara się utrwalać przekonanie o realności sukcesu w ogóle"21. Tak jak każdy może osiągnąć sukces, tak też każdy może zostać politykiem. Jednak trudno o namacalne dowody, nie istnieją też żadne badania, które potwierdzałyby przekonanie Toeplitza, że obcowanie z ludźmi sukcesu za pośrednictwem telewizorów rzeczywiście działa motywująco czy aktywizująco na telewidzów. W większym stopniu można tutaj mówić raczej o tym, co Chudy nazwał „dyspozycyjnością emocjonalną”, która „włącza się racjonalnie w cały system oddziaływań: wyraża ją pozytywność na pokaz i pseudo-luz, życzliwość, obdarowywanie uśmiechami, a także prezentowanie szczęścia i dumy jako przejawu samoświadomości pracowniczej"22. Polityka jednak w takim znaczeniu „dyspozycyjna emocjonalnie” wcale nie jest - mało w mediach masowych jej życzliwej czy uśmiechniętej „twarzy”, zdecydowanie więcej negatywnych emocji, kłótni i sporów, wyzwisk i konfliktu. To w sposób wyraźny odróżnia zmediatyzowaną „rozrywkę polityczną” od typowych programów rozrywkowych.

${ }^{20}$ U. Schnabel, Sztuka leniuchowania. O szczęściu nicnierobienia, przeł. V. Grotowicz, Warszawa 2014, s. 215. Pojęcie flow Ulrich Schnabel pojmuje jak Mihály Csikszentmihalyi, czyli jako „płynięcie”, to znaczy „powiązane z poczuciem szczęścia doświadczenie owego stanu, w którym - tak jak dzieci - zanurzamy się całkowicie w naszym działaniu, przeżywając jednocześnie łatwość bytu, co pozwala nam zapomnieć o wszystkim innym, jako że czas traci na znaczeniu (wiadomo, że szczęśliwi czasu nie liczą)" (U. Schnabel, Sztuka leniuchowania..., dz. cyt., s. 213).

${ }^{21}$ K. T. Toeplitz, Szkice edynburskie..., dz. cyt., s. 84.

22 W. Chudy, Społeczeństwo zakłamane..., dz. cyt., s. 262. 


\section{Polityka jako „spektakularna” kłótnia}

Z jednej strony polityka we współczesnych mediach masowych zajmuje to samo miejsce, co telewizyjna rozrywka, w takim samym stopniu ma również zabawiać widza, absorbować, pochłaniać jego czas i wciągać w swoją fabułę. Z drugiej jednak - dziwna to rozrywka, skoro dominującym w niej motywem jest spór i kłótnia, czasami wręcz wrogość i otwarty, niczym nieskrępowany atak. Sieć politycznych kłótni i sporów staje się odmianą spektaklu, z wszystkimi jego konsekwencjami wyróżnianymi i charakteryzowanymi przez Guy Deborda.

W swoim Społeczeństwie spektaklu precyzuje on, że „spektakl nie jest zwykłym nagromadzeniem obrazów, ale zapośredniczonym przez obrazy stosunkiem społecznym między osobami”; podkreśla, że „w spektaklu nie należy się dopatrywać zwykłego nadużycia technik masowego rozpowszechniania obrazów. Jest to raczej wizja świata, która stała się rzeczywista, znalazła materialny wyraz; uprzedmiotowiony światopogląd"23. Ciąg obrazów przedstawiających zwaśnionych ze sobą polityków buduje w społecznej świadomości przekonanie, że dokładnie tak wygląda sfera polityczna - efektem zaś niniejszego spektaklu jest nowa, „spektakularna" wizja polityki. W przypadku konfliktowej wizji polityki, jaką upowszechniają media masowe, jeszcze bardziej adekwatne wydaje się pojęcie „megaspektaklu” stworzone przez Stevena Besta i Douglasa Kellnera, interpretujących go jako zjawisko, „w którym potęgują się kluczowe procesy społeczeństwa spektaklu”24, z ogłupianiem społeczeństwa na czele. Kłócący się politycy oraz polityka postrzegana jako nieustanny i wręcz egzystencjalny spór stają się niczym kolejny Baudrillardowski symulakr, który nie pokazuje rzeczywistości takiej, jaką ona jest, lecz jedynie ją w szczególny sposób reprezentuje. W świadomości społecznej jednakowoż wszystkie symulakry paradoksalnie „stają się” rzeczywistością, zaś widzowie nie potrafią wyobrazić sobie świata różnego od tychże symulakrów. Skoro więc postrzegają politykę przez pryzmat wojny i walki, to

${ }^{23}$ G. Debord, Społeczeństwo spektaklu, przeł. M. Kwaterko, Warszawa 2006, s. 34.

24 T. Olczyk, Politrozrywka i popperswazja..., dz. cyt., s. 91. 
takiej właśnie polityki oczekują i taką jej wersję - jak utrzymują: prawdziwą - pragną obserwować za pośrednictwem środków masowego przekazu. Także Sartori dostrzega „uprzywilejowanie przez media - chcąc, nie chcąc - emocjonalnej wizji polityki, czyli szukanie w polityce lub sprowadzanie polityki do splotów emocji" ${ }^{25}$. Najprostsze zaś emocje rodzą się podczas obserwacji przemocy, agresji, walki i kłótni.

Oczekiwanie merytorycznej dyskusji i rzeczowej rozmowy, podobnie jak polityczny umiar i rozsądek, zdają się zupełnie nieadekwatne do zmediatyzowanej polityki, która przekształciła się w „spektakl wojny”. Sartori wskazuje, że głównym odpowiedzialnym za ów proces jest odejście w mediach od słowa pisanego, które wyparte zostało przez przekaz opierający się przede wszystkim na obrazie. W Homo vidensie pisze on, że to właśnie „kultura obrazu niszczy delikatną równowagę między namiętnością i racjonalnością. Racjonalność gatunku homo sapiens zdaje się zanikać. Polityka emocjonalna, emocjonująca, podgrzana przez telewizję wywołuje i podsyca problemy, na których rozwiązanie nie ma żadnego pomysłu" ${ }^{26}$. Konflikt skupia uwagę i dlatego dla telewizyjnych producentów jest on łatwym sposobem na podniesienie oglądalności programu. Dla widzów zaś konflikt jest o tyle interesujący, o ile dotyczy spraw związanych z jego życiem codziennym bądź fundamentalnymi wartościami, z którymi się utożsamia. Nie powinno więc dziwić, że większość współczesnych programów publicystycznych opiera się na tej samej formule: dwóch lub więcej gości, z których każdy reprezentuje inne środowisko polityczne, zaś tematyka spotkania dobrana jest w taki sposób, aby goście mieli więcej niż jedną okazję do wejścia w spór z jednym lub większą liczbą rozmówców. Strauss wskazywał, że „sofiści albo utożsamiają naukę o polityce z retoryką, albo też retoryce ją podporządkowują" ${ }^{27}$. Na pewno więc także w takim kontekście moglibyśmy mówić o polityce współczesnej jako o medialnej formie dyskursu, w którym niekoniecznie liczy się konkluzja czy konsensus, ale raczej językowa czy też retoryczna potyczka

25 G. Sartori, Homo videns..., dz. cyt., s. 67.

26 G. Sartori, Homo videns..., dz. cyt., s. 67.

27 L. Strauss, Sokratejskie pytania, dz. cyt., s. 27. 
między dwoma uczestnikami życia publicznego. Bourdieu ponadto podkreśla, że niejednokrotnie i dziennikarz prowadzący taki program staje się de facto uczestnikiem tegoż sporu, czasami mniej bądź bardziej jawnie opowiadając się po którejś ze stron telewizyjnej walki. Trzeba pamiętać bowiem, że to „prowadzący dzieli czas między rozmówców, tonem głosu rozdziela uznanie lub pogardę, zainteresowanie lub zniecierpliwienie"28. Nijak się to ma rzecz jasna do wymogów etycznych stawianych dziennikarzom przez kodeksy etyki dziennikarskiej, w których obiektywizm, niezależność i bezstronność urastają do rangi cnót kardynalnych tejże profesji. Bourdieu dowodzi, że w telewizji „mamy debaty prawdziwie fałszywe, jawnie fałszywe, ich fałsz widać od razu"29. Są to takie debaty, w których nie chodzi o rzeczywiste rozważenie rozbudowanej argumentacji wokół określonego problemu. Chodzi raczej o polaryzację i wywołanie medialnej kłótni. Tym samym współczesne media - również te, które określamy mianem opiniotwórczych - coraz bardziej ulegają naciskowi procesów tabloidyzacyjnych i zjawisku dumbing down, utożsamianemu dziś z systematycznym obniżaniem się poziomu medialnego przekazu.

Strauss napisał o Niccolò Machiavellim, że był on pierwszym w istocie swej nowożytnym filozofem politycznym, gdyż „sprowadził politykę na ziemię" $\mathrm{i}$ urealnił zakres roszczeń filozofii polityki. Machiavelli - zdaniem autora Sokratejskich pytań - zdawał się przyjmować, że „aby opanować przypadek, należy obniżyć standardy, należy spowodować przesunięcie akcentu z charakteru moralnego na instytucje"30. Takim sposobem nowożytna filozofia polityki skupiła się na zagadnieniach organizacji systemu politycznego, odeszła zaś od klasycznego szerokiego rozumienia ustroju. Per analogiam współczesne media w jeszcze większym stopniu urealniły rozumienie polityki, dostosowując je do warunków masowego społeczeństwa egalitarnego, zorganizowanego $\mathrm{w}$ instytucjach demokratycznych. Ponieważ z oczywistych względów nie wszystkich obywateli można gruntownie wykształcić politologicznie, media ma-

28 P. Bourdieu, O telewizji..., dz. cyt., s. 61.

29 P. Bourdieu, O telewizji..., dz. cyt., s. 58.

30 L. Strauss, Sokratejskie pytania, dz. cyt., s. 98. 
sowe poprzestają na prezentowaniu polityki wyłącznie w jej warstwie wizerunkowo-retoryczno-dyskursywnej. Bourdieu wyjaśnia to zjawisko na przykładzie debat telewizyjnych, podczas analiz których uwidacznia się „problem niezwykle istotny z punktu widzenia demokracji: oczywiście nie wszyscy rozmówcy są w tym studiu równi. Mamy tu telewizyjnych zawodowców, niektórzy są jednocześnie zawodowymi mówcami, a naprzeciw nich amatorów" ${ }^{31}$. Podobnie dzieje się przecież po stronie odbiorców: wszyscy mają różną wiedzę i odmienne doświadczenia, zaś polityka i zagadnienia życia publicznego angażują ich w różnym stopniu. Telewizja ma nadzieję, że niekontrolowane emocje i sensacyjność przekazu dotyczącego polityki „zjednoczą” całą widownię i „unieważnią” ich nierówność w zakresie wiedzy i doświadczenia. W rzeczy samej tego typu przekaz medialny - zarówno w swojej formie, jak i treści - dostosowywany jest do masowego odbiorcy, potwierdzając implicite konkluzję José Ortegi y Gasseta z Buntu mas, że „cechą charakterystyczną naszych czasów jest panowanie masy, tłumu, nawet w grupach o elitarnych dotychczas tradycjach. Tak więc także w dziedzinie życia intelektualnego, które z samej swej istoty wymaga określonych kwalifikacji, daje się zauważyć stały wzrost znaczenia pseudointelektualistów, niedouczonych, nie będących w stanie osiągnąć należytych kwalifikacji i którzy z natury rzeczy powinni być w tej dziedzinie zdyskwalifikowani" ${ }^{32}$. Tym bardziej więc $\mathrm{z}$ takim zjawiskiem musimy mieć do czynienia w sferze medialnej, która $z$ natury swej ma charakter radykalnie inkluzywny i egalitarny.

Polaryzacja, jaka zachodzi współcześnie w dyskursie publicznym, dostrzeżona została również przez Sloterdijka, który w Pogardzie mas konkluduje, że „we współczesnych walkach kultur i ideologicznych potyczkach partyjnych obserwujemy na ogół właśnie spór między obrażaczami a pochlebcami” ${ }^{33}$. „Obrażaczem” czy też „pochlebcą” w zależności od określonego kontekstu tematycznego czy sytuacyjnego może być każdy aktor życia medialnego, tym samym również każdy polityk.

31 P. Bourdieu, O telewizji..., dz. cyt., s. 62.

32 J. Ortega y Gasset, Bunt mas, przeł. P. Niklewicz, Warszawa 2006, s. 13.

${ }^{33}$ P. Sloterdijk, Pogarda mas, dz. cyt., s. 46. 
Z kolei w traktacie Musisz życie swe odmienić Sloterdijk spostrzega, że „mediatyzacja objęła także świat oświeconych gier i nieuniknione było, że wśród nauczycieli zgrabnie wyważonej niemożliwości pojawiły się talenty performance" ${ }^{34}$. Ten ostatni wniosek autora Krytyki cynicznego rozumu jest zatrważający. Wynika z niego bowiem, że mediatyzacja objęła właściwie wszystkie sfery ludzkiego życia, niezależnie od tego, jak bardzo niektóre z nich utożsamialibyśmy z przejawami kultury elitarnej czy też wysokiej. Nie dziwi zatem, że choroba ta - wraz z wszystkimi jej negatywnymi skutkami - objęła również świat polityczny. Misyjne oczekiwania względem mediów masowych czy klasyczne pojmowanie polityki jako służby postawione zostają w opozycji wobec zjawiska komercjalizacji i marketyzacji kolejnych sfer życia. Bourdieu zaznacza, że właśnie „telewizja doprowadziła tę sprzeczność do ekstremum, ponieważ w większym stopniu niż wszystkie inne dziedziny produkcji kulturowej poddana była presji komercyjnej (przejawiającej się w kryterium oglądalności)"35. Dychotomizacja przedstawionego świata, przemoc, agresja i konflikt służą oglądalności, a zarazem finansowemu sukcesowi. McLuhan przestrzega jednak, aby konfliktu, przemocy czy agresji nie traktować jako lekarstwa na problemy współczesnej kultury, gdyż „spektakl brutalności, użyty celem odstraszenia, może odnieść skutki wręcz odwrotne" ${ }^{36}$. Nadmierna ekspozycja konfliktu - czy też w szerszym kontekście: ekspozycja zła - raczej widza do konfliktu przyzwyczaja, oswaja go z oglądaną przemocą i zarazem znieczula. Wychowawczy walor ekspozycji zła to jedynie mrzonka. Jak wskazuje Giovanni Cucci, „uwaga poświęcona przez środki masowego przekazu gniewowi przy okazji tragicznych wydarzeń zanotowanych w kronice, ujawnia również ważność tego uczucia, jakiej nabiera ono ze społecznego punktu widzenia, ponieważ gniew dotyczy sfery relacji, przynosi rozpad i zniszczenie" ${ }^{37}$. Wszelkie przejawy zła nadmiernie eks-

\footnotetext{
34 P. Sloterdijk, Musisz życie swe odmienić. O antropotechnice, przeł. J. Janiszewski, Warszawa 2014, s. 399.

${ }^{35}$ P. Bourdieu, O telewizji..., dz. cyt., s. 66.

36 M. McLuhan, Zrozumieć media, w: M. McLuhan, Wybór tekstów, przeł. E. Różalska i J. M. Stokłosa, Poznań 2001, s. 239.

37 G. Cucci, Fascynacja złem. Wady główne, przeł. A. Wojnowski, Kraków 2011, s. 168-169.
} 
ponowane w mediach publicznych skutkować mogą uniewrażliwieniem odbiorcy, jeśli zaś pojawiają się w kontekście sfery politycznej, wówczas zdają się podtrzymywać niezwykle pesymistyczną wizję polityki jako konfliktu i walki, ograniczając jej rozumienie do tego jednego aspektu.

\section{Polityka jako manipulacja masami}

Nie można nie spojrzeć na zmediatyzowaną politykę współczesną jako na kolejne narzędzie panowania nad człowiekiem, jako na kolejne narzędzie manipulacji odbiorcą, który w sposób bierny i niejednokrotnie nieświadomie ulega wpływowi mediów i polityków w nich obecnych. Sloterdijk - odpowiadając na rozważania Michela Foucaulta z m.in. Nadzorować i karać - wskazuje dobitnie, że „to nie więzienia i miejsca uciskającego nadzoru, lecz surowe często szkoły i szkoły wyższe nowożytności, a także warsztaty rzemieślników i atelier artystów są tymi miejscami, w których praktykowana jest w nowoczesności ortopedia istoty ludzkiej”38. Czy jednak nie wydaje się, że współcześnie większe znaczenie od szkoły nawet w procesie - jak zwie Sloterdijk - „ortopedii istoty ludzkiej” odgrywają media masowe? Zmediatyzowana polityka widziana jako rozrywka i nieustanny konflikt staje się elementem współczesnej paidei - choć pewnie poprawniej byłoby powiedzieć anty-paidei - która formuje nowego człowieka: człowieka zmediatyzowanego czy też Sartoriańskiego homo vidensa. W tym kontekście przypominają się słowa Straussa wskazujące, że „człowiek jest niewolnikiem z natury, jeśli jest zbyt głupi, by kierować sam sobą, albo też jeśli nie jest w stanie wykonywać pracy tylko niewiele bardziej skomplikowanej niż ta, którą wykonują zwierzęta domowe" ${ }^{39}$. Zapewne w realiach społeczeństwa masowego i zmediatyzowanego uprawnione byłoby mówienie o nowym niewolnictwie, przejawem którego są pasywizm, otępienie i znieczulenie odbiorcy medialnych komunikatów. Cały proces komunikacyjny - także komunikacja między tzw. elitami politycznymi a społeczeństwem - ulega

38 P. Sloterdijk, Musisz życie swe odmienić..., dz. cyt., s. 439.

39 L. Strauss, Sokratejskie pytania, dz. cyt., s. 32-33. 
głębokiej trywializacji. Uproszczone komunikaty docierają w równym stopniu i z równą skutecznością do wszystkich odbiorców, wobec czego nie jest konieczne indywidualizowanie przekazów medialnych pod kątem zdolności percepcyjnych, wiedzy i umiejętności widzów. Sloterdijk mówi ostro, że nie jest to nic innego, jak „poniżenie człowieka wskutek trywialnych komunikacji”" ${ }^{30}$. Co ciekawe, tej władzy nad odbiorcą, którą umożliwiają mechanizmy manipulacji, chcą nie tylko politycy, ale również ludzie mediów. Claude-Jean Bertrand mówi, że ich żądza władzy w istocie staje się sojusznikiem żądzy władzy, którą owładnięci są niektórzy (a może wszyscy?) politycy. Jego zdaniem „każdy (zarówno właściciel, jak i pracownik) na swój sposób ma świadomość i przekonanie, że dysponuje pewną władzą. Rozkoszuje się mówieniem o «mediokracji», sądząc, że może wywierać wpływ na decydentów oraz opinię publiczną, chociażby poprzez pomijanie pewnych faktów milczeniem"41.

Manipulacja odbiorcą - jak wskazuje Bourdieu - zaczyna się na bardzo wczesnym etapie przygotowania materiałów. $\mathrm{W}$ proces ten zaangażowani są nie tylko politycy, których celem jest wykreowanie i utrwalenie własnego pozytywnego wizerunku oraz wykorzystanie mediów masowych w tym właśnie celu. Autor Rozumu praktycznego dostrzega, że „wpływ i panowanie mediów zaznacza się już w charakterystycznym dla pola dziennikarskiego sposobie stawiania pewnych pytań i wymuszaniu na polu intelektualnym odpowiedzi (rzecz jasna krótkich, a przy tym zrozumiałych «dla wszystkich»), także na źle postawione pytania”" ${ }^{\text {. }}$. Sposób postawienia pytania implikuje bowiem sposób udzielenia odpowiedzi przez zapytanego. Jedno i drugie zaś odgrywają kluczowe znaczenie w kształtowaniu świata wyobrażonego ostatecznych odbiorców komunikatów medialnych. Komunikaty medialne polityków bynajmniej nie muszą dotyczyć rzeczywistych problemów, przed którymi staje państwo czy społeczność międzynarodowa, nie muszą również podejmować merytorycznych zagadnień, w szczególności zaś takich, które mogłyby oka-

40 P. Sloterdijk, Pogarda mas, dz. cyt., s. 80.

41 C.-J. Bertrand, Deontologia mediów, przeł. T. Szymański, Warszawa 2007, s. 236.

${ }^{42}$ M. Jacyno, Przedmowa do wydania polskiego, w: P. Bourdieu, O telewizji..., dz. cyt., s. 20-21. 
zać się zbyt skomplikowane na ich wyjaśnienie podczas kilkuminutowej obecności w środkach masowego przekazu. Sartori nie ma najmniejszych wątpliwości, że „politycy coraz rzadziej odnoszą się do realnych, «nieobrobionych» wydarzeń, coraz częściej zaś do "wydarzeń medialnych», czyli do wydarzeń, które poddano selekcji pod kątem ich telegeniczności, następnie rozdęto ich znaczenie $\mathrm{w}$ wyniku obecności kamery, a czasami nawet zmieniono ich sens" ${ }^{\prime 3}$. Takim sposobem świat, o którym ze sobą rozmawiają politycy i ludzie mediów, wydaje się jedynie światem rzeczywistym, zaś w istocie swej jest światem sztucznie stworzonym przez medialny dyskurs. Taki świat wyobrażony - Baudrillardowski symulakr odpowiednio często eksponowany w mediach masowych - sprawia, że tzw. przeciętny odbiorca zaczyna utożsamiać go ze światem rzeczywistym, a tym samym traci kontakt $\mathrm{z}$ wszystkim tym, co w mediach się nie pojawia. Inwazja „wydarzeń medialnych” - czy też poprawniej: „faktów medialnych" - dotknęła nie tylko tabloidów, ale również doskwiera mediom opiniotwórczym. Ów zmanipulowany obraz świata podporządkowany jest rzecz jasna potrzebom polityków i świata mediów. Szczególną rolę odgrywa tutaj telewizja, która - jak pokazuje Bourdieu - jest „uniwersum, w którym odnosimy wrażenie, że aktorzy społeczni, zachowując wszelkie pozory ważności, wolności, autonomii, a czasem nawet niesamowitości (wystarczy czytać gazety telewizyjne), są tylko kukiełkami w rękach konieczności, którą trzeba opisać, struktury, którą trzeba odkryć i ujawnić" ${ }^{44}$. W rzeczywistości jednak odbiorca nic nie odkrywa, w szczególności zaś nie odkrywa realnego świata, lecz przyswaja jedynie wygenerowaną kreację.

Medialne manipulacje nie byłyby tak skuteczne, gdyby nie istnienie społeczeństwa masowego, które wykazuje się szczególną biernością i uległością wobec rzeczywistości medialnej, w tym sfery politycznej prezentującej się za pośrednictwem środków masowego przekazu. Sloterdijk potwierdza to spostrzeżenie, wskazując, że „dzisiejsze masy zasadniczo przestały być masami zgromadzeń i weszły w skład reżimu,

${ }^{43}$ G. Sartori, Homo videns..., dz. cyt., s. 66.

${ }^{44}$ P. Bourdieu, O telewizji..., dz. cyt., s. 67. 
w którym charakter masy nie wyraża się fizycznym zgromadzeniem, lecz udziałem w programach mass mediów" ${ }^{45}$. Współczesna masa jest więc paradoksalnie masą rozproszoną, masą siedzącą przed milionami telewizorów i łączącą się jedynie w korzystaniu z tych samych kanałów czy programów telewizyjnych. Współczesna masa nie potrzebuje styczności przestrzennej - wystarcza jej łączność psychiczna, jaką gwarantuje jej możliwość zanurzania się w wykreowanej przez media rzeczywistości wyobrażonej. W Pogardzie mas czytamy, że „masa-zbiegowisko stała się masą objętą pewnym programem - i jako taka z definicji skończyła z fizycznym gromadzeniem się w jednym miejscu" ${ }^{46}$. Specyfika społeczeństwa masowego umożliwiła więc politykom zmianę podejścia do relacji między nimi a potencjalnymi wyborcami. Marketing bezpośredni został zepchnięty na dalszy plan, a pierwszeństwo uzyskały narzędzia socjotechniki oraz reklama polityczna. Spotkania z wyborcami straciły swoją atrakcyjność, bowiem politycy mogą „wirtualnie” spotkać się z całym społeczeństwem za pośrednictwem mediów masowych. Skrzętnie przygotowywane programy polityczne, których przecież nigdy nikt nie czytał, zostały skutecznie zastąpione nie tylko skrótowymi deklaracjami programowymi, ale wręcz kilkoma hasłami, które tym łatwiej zapadają w pamięci odbiorcom, im częściej pojawiają się w przestrzeni medialnej. Sartori wskazuje, że tak jak niegdyś politycy byli uzależnieni od struktur partyjnych, tak teraz uzależnieni są od obecności w mediach. Prognozuje, że „podążamy ku modelowi przedstawiciela [...] zależnego od telewizji oraz zależnego od sondaży" ${ }^{47}$. Zanim więc polityk będzie mógł zaprezentować swój komunikat i trafić nim do świadomości społecznej, będzie musiał zatroszczyć się o zdobycie możliwości „zdalnego” wystąpienia na forum jakiegoś medium. To zaś sprawia, że ostateczną instancją decyzyjną stają się właściciele, producenci oraz autorzy programów telewizyjnych.

Media masowe wespół z zmediatyzowanymi politykami, tworząc de facto równoległy świat wyobrażony, zniewalają odbiorców mniemaniami,

45 P. Sloterdijk, Pogarda mas, dz. cyt., s. 22.

46 P. Sloterdijk, Pogarda mas, dz. cyt., s. 23.

47 G. Sartori, Homo videns..., dz. cyt., s. 65. 
a oddalają od rzetelnej wiedzy, której w klasycznej koncepcji funkcji mediów byśmy od niech oczekiwali. Strauss przestrzega, że „wszelka wiedza polityczna jest otoczona przez opinię polityczną i urozmaicona przez nią. Opinię polityczną rozumiemy tutaj jako coś różnego od wiedzy: błędy, przypuszczenia, przesądy, przewidywania i tak dalej. Do istoty życia politycznego należy uleganie mieszaninie politycznej wiedzy i politycznej opinii”48. Ta mieszanina politycznej wiedzy i politycznej opinii kształtuje współczesnego człowieka, który swój obraz sfery politycznej buduje wyłącznie na przekazach generowanych przez środki masowego przekazu. A przecież tak trudno dziś znajomość tej sfery budować na innych źródłach. Mniej wprawiony widz zwyczajnie nie jest w stanie odróżnić wiedzy od mniemania, a opinia medialna staje się dla niego niejednokrotnie bagażem niepodważalnej prawdy. Wielu współczesnych medioznawców podkreśla, że „media działają bowiem także jako wzorzec lub wyzwalacz zachowań znajdujących się w poznawczym repertuarze danej osoby" " Nie tylko tworzą nasz świat wyobrażony, ale kształtują nasze postawy względem rzeczywistego świata, w którym realnie funkcjonujemy. Wizerunek medialny polityka zostaje przez widzów utożsamiony z polityczną rzeczywistością, toteż rodząca się na jego bazie postawa jest reaktywna przede wszystkim względem polityki realnej, nie zaś względem wizerunkowych kreacji. Medialne wypowiedzi polityków to „wyzwalacze zachowań", szczególnie wtedy gdy odwołują się do emocji odbiorców bądź bazują na wartościach, do których odbiorcy są głęboko przywiązani. Przekaz medialny polityka - aby sprostać wymogom ekspozycji medialnej - musi w pierwszej kolejności „rzucać się w oczy”, a to już typowa cecha wynikająca $\mathrm{z}$ funkcjonowania sfery politycznej w realiach kultury masowej, bo przecież - zgodnie ze słowami Sloterdijka - „kultura masowa wszelkich epok będzie związana z próbą uczynienia czegoś nieinteresującego czymś najbardziej rzucającym się w oczy"50. Telewizja

48 L. Strauss, Sokratejskie pytania, dz. cyt., s. 66.

49 D. Kubicka, Modele procesów perswazji w komunikacji masowej, w: Psychologia wptywu mediów. Wybrane teorie, metody, badania, red. D. Kubicka, A. Kołodziejczyk, Kraków 2007, s. 72.

50 P. Sloterdijk, Pogarda mas, dz. cyt., s. 70. 
jeszcze bardziej wzmacnia tę cechę poprzez nachalne operowanie obrazem, gdyż - jak wskazywał Sartori - „nadmiar widzenia znieczula naszą zdolność rozumowania" ${ }^{51}$. Polityka zmediatyzowana nie ma więc być bodźcem do politycznego namysłu czy refleksji wokół spraw publicznych, jej głównym zadaniem jest skłonienie odbiorcy polityczno-medialnego komunikatu do określonej reakcji. Przed erą telewizji prawdą było niewątpliwie, że „wódz czy też każdy, kto reprezentuje jakąś ideę, tylko wtedy osiąga sukces [...], kiedy jego osobiste poglady, ideologia lub program potrącaja jakieś struny w przeciętnej strukturze mas" ${ }^{\prime 2}$. Współcześnie to nie poglądy, ideologia lub program mają „potrącać jakieś struny w przeciętnej strukturze mas" - dziś taką rolę ma odgrywać ekspozycja medialna polityka, jego wizerunek, wypowiedzi i retoryka.

\section{Bezsensowny umiar - zakończenie}

Umiar i rozsądek to nie są wartości, które we współczesnej rzeczywistości medialnej są w stanie zawładnąć tłumami odbiorców. Również w odniesieniu do spraw politycznych i publicznych wartości te nie należą do propagowanych. Polityczna pseudorefleksja, jaką obserwujemy w mediach masowych, nie rozwiązuje żadnych problemów ani nie buduje wizji przebudowy otaczającego nas porządku. Szczególnego znaczenia nabierają w tym kontekście słowa Straussa ubolewającego nad tym, że „dzisiaj filozofia polityki jest $\mathrm{w}$ stanie upadku i zapewne gnicia, jeśli nie zniknęła już ona całkowicie"53. Obserwacja polityki zmediatyzowanej może nas skłaniać jednak do jeszcze bardziej radykalnych wniosków: to już nie tylko filozofia polityki znalazła się w stanie upadku i gnicia, ale polityka sui generis systematycznie upada i gnije. Polityka zwrócona w swojej istocie ku światu i skupiona na jego organizacji w dobie społeczeństwa masowego i konsumpcyjnego jakby traci z tym światem jaki-

51 G. Sartori, Homo videns..., dz. cyt., s. 30.

52 W. Reich, Psychologia mas wobec faszyzmu, przeł. E. Drzazgowska, M. Abraham-Diefenbach, Warszawa 2009, s. 54.

53 L. Strauss, Sokratejskie pytania, dz. cyt., s. 68. 
kolwiek związek. Wynika to - jak spostrzegł Baudrillard - ze sposobów działania samych mediów, z faktu, że „środki masowego przekazu nie kierują nas do świata, lecz dostarczają nam do skonsumowania znaki jako takie, wszelako z atestem i poręką rzeczywistości" ${ }^{54}$. Atestu i poręki dostarczają współcześni celebryci - zarówno proweniencji politycznej, jak też medialnej - we współpracy z instytucjami medialnymi, które nadal roszczą sobie pretensje do miana organizacji zaufania publicznego. Zarówno ludzie mediów, jak też politycy, jeśli pragną stać się głównymi aktorami medialno-politycznego spektaklu, muszą dostosować swój wygląd, zachowanie i przekaz do warunków, jakie narzucają telewizyjne programy rozrywkowe. Frédéric Martel pyta: „Czy żeby wejść do mainstreamu i przemówić do wszystkich, trzeba uprzywilejować i wspierać entertainment?" 55 , jednak jego pytanie w świetle niniejszych rozważań należy ze smutkiem uznać za retoryczne.

Ucieczka od umiaru, której przejawem jest zmiana postrzegania istoty polityki w dobie panowania mediów masowych, w pierwszej kolejności wydaje się konsekwencją przesuwania się od początku dwudziestego wieku społeczeństw w kierunku społeczeństw masowych. Baudrillard twierdzi, że „masy dryfują gdzieś pomiędzy biernością i nieokiełznaną spontanicznością, zawsze jednak jako energia potencjalna, rezerwa społeczności i społecznej energii" ${ }^{56}$. Dokładnie w taki sposób zachowuje się masowy odbiorca medialnego przekazu okołopolitycznego: miota się między biernością siedzenia przed ekranem telewizora a spontanicznością emocjonalnych reakcji, które prowokują medialno-polityczni aktorzy. Po drugie ucieczka od umiaru jest również pochodną procesu urynkowienia kolejnych sfer życia społecznego, który w ostatnim półwieczu ogarnął również sferę polityczną, czego przykładem może być chociażby coraz większe znaczenie socjotechniki i marketingu politycznego. Wojciech

\footnotetext{
54 J. Baudrillard, Społeczeństwo konsumpcyjne. Jego mity i struktury, przeł. S. Królak, Warszawa 2006, s. 21.

55 F. Martel, Mainstream. Co podoba się wszędzie na świecie, przeł. K. Sikorska, Warszawa 2011, s. 402 .

56 J. Baudrillard, W cieniu milczącej większości albo kres sfery społecznej, przeł. S. Królak, Warszawa 2006, s. 7.
} 
Cwalina i Andrzej Falkowski podkreślają, że współczesny polityk „dopiero odpowiednio «opakowany» ma szansę odnieść sukces wyborczy. Czasem odbywa się to kosztem chwilowej utraty tożsamości czy też kłamstwa" ${ }^{57}$. Polityk staje się takim samym towarem, jak proszek do prania czy samochód, zaś wyborca, czyli odbiorca medialno-politycznego komunikatu, przeistacza się w klienta, który rozgląda się za właściwym obiektem. Po trzecie ucieczka od umiaru to zarazem oddanie się bezrefleksyjnemu i pasywnemu konsumpcjonizmowi, który wypełnia nam czas wolny i odwraca uwagę od tego, co kilkadziesiąt lat wcześniej uznalibyśmy za ważne i godne dążenia. George Ritzer wskazuje, że „z perspektywy bliższej współczesności zarówno ostentacyjne próżnowanie, jak i ostentacyjną konsumpcję trzeba by widzieć jako podstawę konsumpcji towarów. Rejs statkiem i wycieczka do kasyna są towarem w stopniu nie mniejszym niż mercedes czy futro z norek"58. Takim właśnie sposobem współczesna polityka przekształca się pod wpływem procesów kulturowych i społecznych. Sprawiają one, że to, jak politykę widzieli klasycy, staje się nie tylko nieaktualne, ale wręcz nieprzystające do współczesnych realiów. Umiar - ta uniwersalna zdawałoby się cnota - jakoś nie może się przebić, zaś w sferze politycznej zyskuje niemalże rangę anachronizmu.

\section{Bibliografia}

Baudrillard J., Społeczeństwo konsumpcyjne. Jego mity i struktury, przeł. S. Królak, Warszawa 2006.

Baudrillard J., W cieniu milczącej większości albo kres sfery społecznej, przeł. S. Królak, Warszawa 2006.

Bertrand C.-J., Deontologia mediów, przeł. T. Szymański, Warszawa 2007.

Bourdieu P., O telewizji. Panowanie dziennikarstwa, przeł. K. Sztandar-Sztanderska, Warszawa 2009.

57 W. Cwalina, A. Falkowski, Marketing polityczny. Perspektywa psychologiczna, Gdańsk 2006, s. 147.

58 G. Ritzer, Magiczny świat konsumpcji, przeł. L. Stawowy, Warszawa 2009, s. 330. 
Chudy W., Społeczeństwo zakłamane. Esej o społeczeństwie i kłamstwie - 1, Warszawa 2007. Cucci G., Fascynacja złem. Wady główne, przeł. A. Wojnowski, Kraków 2011.

Cwalina W., Falkowski A., Marketing polityczny. Perspektywa psychologiczna, Gdańsk 2006.

Dahl R. A., Demokracja i jej krytycy, przeł. S. Amsterdamski, Warszawa 2012.

Debord G., Społeczeństwo spektaklu, przeł. M. Kwaterko, Warszawa 2006.

Jacyno M., Przedmowa do wydania polskiego, w: P. Bourdieu, O telewizji. Panowanie dziennikarstwa, przeł. K. Sztandar-Sztanderska, Warszawa 2009, s. 7-32.

Kubicka D., Modele procesów perswazji w komunikacji masowej, w: Psychologia wpływu mediów. Wybrane teorie, metody, badania, red. D. Kubicka, A. Kołodziejczyk, Kraków 2007, s. 7-9.

Martel F., Mainstream. Co podoba się wszędzie na świecie, przeł. K. Sikorska, Warszawa 2011. McLuhan M., Przekaźniki, czyli przedłużenie człowieka, w: M. McLuhan, Wybór pism: Przekaźniki, czyli przedłużenie człowieka. Galaktyka Gutenberga. Poza punktem zbiegu, przeł. K. Jakubowicz, Warszawa 1975, s. 43-208.

McLuhan M., Zrozumieć media, w: M. McLuhan, Wybór tekstów, przeł. E. Różalska i J. M. Stokłosa, Poznań 2001, s. 209-258.

McNair B., Seks, demokratyzacja pożądania i media, czyli kultura obnażania, przeł. E. Klekot, Warszawa 2004.

Olczyk T., Politrozrywka i popperswazja. Reklama polityczna w polskich kampaniach wyborczych XXI wieku, Warszawa 2009.

Ortega y Gasset J., Bunt mas, przeł. P. Niklewicz, Warszawa 2006.

Psychologia wpływu mediów. Wybrane teorie, metody, badania, red. D. Kubicka, A. Kołodziejczyk, Kraków 2007.

Reich W., Psychologia mas wobec faszyzmu, przeł. E. Drzazgowska, M. Abraham-Diefenbach, Warszawa 2009.

Ritzer G., Magiczny świat konsumpcji, przeł. L. Stawowy, Warszawa 2009.

Sartori G., Homo videns. Telewizja i postmyślenie, przeł. J. Uszyński, Warszawa 2007.

Sloterdijk P., Musisz życie swe odmienić. O antropotechnice, przeł. J. Janiszewski, Warszawa 2014.

Sloterdijk P., Pogarda mas, przeł. B. Baran, Warszawa 2012.

Schnabel U., Sztuka leniuchowania. O szczęściu nicnierobienia, przeł. V. Grotowicz, Warszawa 2014.

Strauss L., Sokratejskie pytania, przeł. P. Śpiewak, Warszawa 1998.

Toeplitz K. T., Szkice edynburskie, czyli system telewizji, Warszawa 1979. 


\section{Abstrakt}

\section{Ucieczka od umiaru. Polityka w erze mediów masowych}

Zasadniczym celem tekstu jest wykazanie, że w dobie mediów masowych dochodzi do zmiany postrzegania i funkcjonowania zjawiska, jakim jest polityka. Jednym z przejawów tejże zmiany jest ucieczka od umiaru, czyli wyrugowanie cnoty umiaru z katalogu wartości kluczowych w działalności politycznej. Polityka zatraca swoje klasyczne znaczenie jako działanie, którego celem jest realizacja jakiegoś dobra wspólnego ( $p$ ublico bono). Z punktu widzenia problemu ucieczki od umiaru współczesna polityka jawi się jako: (1) polityka postrzegana jako rozrywka, (2) polityka postrzegana jako „spektakularna” kłótnia, (3) polityka postrzegana jako manipulacja masami.

\section{Słowa klucze}

polityka, tabloidyzacja, komunikacja społeczna, manipulacja

\section{Abstract}

\section{Escape from Moderation. Politics in the Mass Media Era}

The main aim of the text is to show that there is a change of perception and functioning of the phenomenon of politics in the era of mass media. One of the manifestations of that change is the escape from restraint or ousting the virtue of moderation from the value catalogue of political activity. Politics loses its traditional meaning as an activity whose aim is the realization of a common good (publico bono). From this point of view contemporary politics appears as: (1) politics understood as entertainment, (2) politics understood as quarell and dispute, (3) politics understood as manipulation of the masses.

\section{Keywords}

politics, tabloidization, social communication, manipulation 